\title{
Retinoic Acid Modulates PTGDR Promoter Activity
}

\author{
Garcia-Sánchez A ${ }^{1,2}$, Marcos-Vadillo E $E^{2,3}$, Sanz $C^{2,4}$, Hernández-Hernández L2, \\ Cerutti-Müller $\mathrm{G}^{5}$, Marqués-García F ${ }^{2,3}$, Lorente $\mathrm{F}^{1,2,6}$, Isidoro-García $\mathrm{M}^{2,3,7}$, \\ Dávila |1,2,8
}

\author{
'Department of Biomedical and Diagnostic Science, University of Salamanca, Salamanca, Spain \\ ${ }^{2}$ Biomedical Research Institute of Salamanca, IBSAL, Salamanca, Spain \\ ${ }^{3}$ Department of Clinical Biochemistry, Salamanca University Hospital, Salamanca, Spain \\ ${ }^{4}$ Department of Microbiology and Genetics, University of Salamanca, Spain \\ ${ }^{5}$ Universidade do Vale do Rio dos Sinos-UNISINOS, São Leopoldo, Brazil \\ ${ }^{6}$ Department of Pediatrics, Salamanca University Hospital, Salamanca, Spain \\ ${ }^{7}$ Department of Medicine, University of Salamanca, Salamanca, Spain \\ ${ }^{8}$ Department of Immunoallergy, Salamanca University Hospital, Salamanca, Spain
}

J Investig Allergol Clin Immunol 2016; Vol. 26(4): 249-255

doi: $10.18176 /$ jiaci.0042

\begin{abstract}
Background and Objective: Vitamin A has been linked to the development of allergic diseases although its role is not fully understood, Retinoic acid (RA), a metabolite of Vitamin A, has been previously associated with the prostaglandin pathway, and PTGDR, a receptor of PGD2, has been proposed as a candidate gene in allergy and asthma. Considering the role of PTGDR in allergy, the goal of this study was to analyze the effect of RA on the activation of the promoter region of the PTGDR gene.

Methods: A549 lung epithelial cells were transfected with 4 combinations of genetic variants of the PTGDR promoter and stimulated with all-trans RA (ATRA); luciferase assays were performed using the Dual Luciferase Reporter System, and real-time quantitative polymerase chain reaction was used to measure the expression of PTGDR, CYP26A1, RARA, RARB, RARG, and RXRA in basal A549 cell cultures and after ATRA treatment. We also performed an in silico analysis.

Results: After ATRA treatment increased expression of CYP26A1 (12-fold) and RARB (4-fold) was detected. ATRA activated PTGDR promoter activity in transfected cells $(P<.001)$ and RA response element sequences were identified in silico in this promoter region.

Conclusions: RA modulated PTGDR promoter activity. Differential response to RA and to new treatments based on PTGDR modulation could depend on genetic background in allergic asthmatic patients.
\end{abstract}

Key words: Allergic asthma. Polymorphisms. PTGDR. Retinoic acid.

\section{Resumen}

Introducción y Objetivo: La vitamina A se ha relacionado con el desarrollo de las enfermedades alérgicas, si bien su papel no se comprende en su totalidad. El ácido retinoico, un metabolito de la vitamina A, se ha asociado previamente con la ruta de las prostaglandinas. Además, PTGDR, uno de los receptores de PGD2, se ha propuesto como un gen candidato en la alergia y el asma. Considerando el papel de PTGDR en la alergia, el objetivo de este estudio fue analizar el efecto del ácido retinoico sobre la activación de la región promotora del gen PTGDR. Métodos: Se utilizó la línea celular A549 de epitelio de pulmón. Las células fueron transfectadas con cuatro combinaciones de las variantes génicas de PTGDR y fueron estimuladas con ácido retinoico todo-trans (ATRA). Los ensayos de Luciferasa se llevaron a cabo mediante el sistema Dual Luciferase Reporter System. Se realizaron análisis de RT-qPCR para medir la expresión basal de PTGDR, CYP26A1, RARA, RARB, RARG y RXRA de los cultivos de A549 tras el tratamiento con ATRA. Se realizaron también análisis bioinformáticos.

Resultados: Se encontraron diferencias significativas en la actividad promotora entre las variantes haplotípicas tras la transfección en la línea celular A549. Tras el tratamiento con ATRA se detectó un incremento de la expresión de CYP26A1 (12 veces) y RARB (4 veces). El 
ácido retinoico activó la actividad promotora de PTGDR en las células transfectadas $(p<0,001)$. Se identificaron secuencias de Elementos de Respuesta a Ácido Retinoico (RARE) in silico en la región promotora de PTGDR.

Conclusiones: El ácido retinoico modula la actividad promotora de PTGDR. Esto podría explicar las diferencias en los efectos del ácido retinoico y en las respuestas a los nuevos tratamientos de la enfermedad alérgica basados en la modulación del receptor PTGDR.

Palabras clave: Asma alérgica. Polimorfismos. PTGDR. Ácido retinoico.

\section{Introduction}

Asthma and allergic diseases are believed to result from the interaction between multiple genes and environmental stimuli. Several features associated with a westernized lifestyle have been suggested as possible causes of the increased prevalence of allergy, including, among others, greater exposure to indoor allergens, changes in exposure to contaminants and pollutants, a reduced rate of infectious diseases, and a Western diet [1]. Western dietary patterns are associated with a decreased intake of fruit and vegetables (sources of antioxidant vitamins and carotenoids) and consequently a decreased intake of vitamins $\mathrm{E}$ and A. Epidemiological studies have reported results on the association between vitamin A and allergy, and several studies have indicated that vitamin $\mathrm{A}$ affects the balance between type 1 helper $\mathrm{T}$ cells $\left(\mathrm{T}_{\mathrm{H}} 1\right)$ and $\mathrm{T}_{\mathrm{H}} 2[2,3]$. The effect of vitamin A has been studied in OVA-induced allergic mouse models of asthma [4] and an important role in regulatory $\mathrm{T}$ cell differentiation and function has also been described for this vitamin [5], although the underlying mechanisms are not fully understood. The role of all-trans retinoic acid (ATRA) in asthma and allergic disease is controversial. While some studies have found vitamin A deficiency to be associated with an increased risk of atopic disease [6], others have reported that it may exert a protective effect against asthma, and that vitamin A supplementation is associated with increased airway hyperresponsiveness [4].

ATRA is a biologically active metabolite of vitamin A that exerts profound effects on T-cell activation, differentiation, and function [7]. It mainly regulates gene transcription through 2 families of nuclear receptors: the RA receptors (RAR- $\alpha,-\beta,-\gamma$ ) and the retinoid $\mathrm{X}$ receptors (RXR- $\alpha,-\beta,-\gamma)[8]$. In certain circumstances, it may also regulate the nuclear receptor PPAR $\beta$ [9].

Effects of RA on prostaglandin pathways have also been reported, with increased cyclooxygenase 2 (COX-2) expression and prostaglandin $\mathrm{E}_{2}\left(\mathrm{PGE}_{2}\right)$ production induced by ATRA [10]. The biosynthesis of $\mathrm{PGD}_{2}$ is mediated by 2 isoforms: lipocalintype prostaglandin D synthase (LPGDS), present in the central nervous system and the genital organs, and the hematopoietic isoform (HPGDS), present fundamentally in mast cells and $\mathrm{T}_{\mathrm{H}} 2$ lymphocytes [11]. LPGDS is a retinoid transporter capable of binding ATRA [12]. PGD $_{2}$, in turn, is the most abundant COX metabolite of arachidonic acid produced by mast cells in response to environmental allergens [13]. It exerts its biological actions through the specific transmembrane receptors PTGDR and CRTH2 [11]. An association between allergy and PTGDR promoter polymorphisms has been previously reported, with studies showing that $P T G D R$ promoter regions are capable of binding transcription factors, and therefore of controlling PTGDR expression, which could be associated with the development of asthma susceptibility [14-16]. Considering the above, we hypothesized that the possible role of RA in the regulation of the immune response might involve PTGDR. The objective of this study was to analyze the effect of RA on the activation of the promoter region of the PTGDR gene.

\section{Methods}

\section{Cell Culture}

The A549 epithelial lung cell line was kindly provided by Dr Odero (CIMA, University of Navarra) and maintained in RPMI with 10\% FBS (Gibco, Invitrogen-Life Technologies) in a humidified atmosphere with $5 \% \mathrm{CO}_{2}$ at $37^{\circ} \mathrm{C}$. This lung cell line has been used to analyze $P T G D R$ expression in previous asthma susceptibility studies [14].

\section{Reagents}

ATRA stock solutions were made in DMSO (both from Sigma-Aldrich) and added directly to the cell culture media to produce the final concentration.

\section{Identification of A549 Sequence Variants}

Genomic DNA from the A549 cell line was isolated with the MagNA Pure Nucleic Acid Isolation Kit using the MagNA Pure Compact instrument (Roche). Genomic DNA was screened for mutations in the promoter region of $P T G D R$ by polymerase chain reaction (PCR) using the oligonucleotide sense primer 5'-CTC AGT TTC CTC GCC TAT GC-3' and the anti-sense primer 5'-GAG TGAAGG CTG CGG AAG GG-3'. PCR products were cleaned with exoSAP-IT (USB-Affimetrix) prior to sequencing in an ABI Prism 3100 Genetic Analyzer (Applied Biosystems-Thermo Scientific).

\section{Plasmid Preparation}

Four PTGDR reporter constructs of 700 base pairs (bp) were created by PCR amplification of genomic DNA from asthmatic patients who had the following alternative homozygous haplotypes at positions $-613,-549,-441$, and -197: CTCT, CCCT, TCCT, and CCCC. The primers used included the $X h o I$ and $B g l I I$ recognition sites. To create a model that reflected the clinical context as closely as possible, the 700-bp sequence selected comprised the 4 most widely studied variants so far and the combinations chosen were the most frequently observed combinations in our patients 
with asthma $[15,16]$. The rest of the sequence was wild type. Amplicons were cloned into the plasmid pSC-A-amp/kan of StrataClone (Stratagene, Agilent Technologies). The constructs generated were subcloned and ligated into multicloning sites of the firefly luciferase pGL3-Basic Vector (Promega). Plasmid DNA was purified with Maxiprep (Qiagen). The pGL3-Basic Vector was also a kind gift from Dr Odero.

\section{Real-Time Quantitative PCR}

PTGDR, CYP26A1, RARA, RARB, RARG, and RXRA expression analysis was also performed in basal human A549 cell cultures and in cells treated with $0.01 \mu \mathrm{M}, 1 \mu \mathrm{M}$ ATRA, or DMSO as a vehicle and incubated for 24 and 48 hours. Total RNA was isolated using the RNeasy Plus Mini kit (Qiagen) according to the manufacturer's instructions. DNAse treatment was performed using Turbo DNAse (Ambion). cDNA was generated using Superscript III (Life Technologies). Relative quantitative PCR was performed using the LightCycler 480 Instrument and SYBR Green I Master (Roche). Fold induction was calculated using the formula 2-( $\Delta \Delta \mathrm{Ct})$. PCR product quality was monitored using post-PCR melt curve analysis. Data are expressed as fold change relative to RNA levels for DMSO-treated cells. The experiments were performed in triplicate.

\section{Transient Transfections and Luciferase Assays}

A549 transient transfection was carried out with Lipofectamine reagent 2000 (Invitrogen) according to the manufacture's protocol. Fifty to seventy percent confluent cells seeded on 24-well plates were transfected with $500 \mathrm{ng}$ of reporter plasmid (pCTCT-PTGDRluc, pCCCC$P T G D R$ luc, pCCCT-PTGDRluc, and pTCCT-PTGDRluc) and cotransfected with $10 \mathrm{ng}$ of the PRL SV 40 vector (Renilla, Promega) to monitor transfection efficiency. After 5 hours, the transfection medium was removed and replaced with fresh medium with antibiotics. Twelve hours after transfection, the cells were lysed. Firefly and Renilla luciferase activity was measured in a LumiStar Omega Luminometer (BMG LabTech) using the Dual-Luciferase Reporter Assay System (Promega). Transfection efficiency was corrected by normalizing Firefly luciferase activity to Renilla luciferase activity. Each assay condition was performed using 3 replicates. Reporter activity was expressed as mean (SD) activity.

\section{RA Treatment in Transient Transfections}

Cells were seeded in RPMI serum-free medium 24 hours before the transfection assay. After 5 hours of the abovementioned transient transfections, the transfection medium was replaced by RPMI supplemented with $1 \%$ FBS and cultures were treated with $1 \mu \mathrm{M}$ ATRA or DMSO as a vehicle and incubated for 12 and 48 hours. The cells were lysed and Firefly and Renilla luciferase activity was measured as previously mentioned. The experiments were replicated 3 times.

\section{In Silico Characterization of Transcription Factors}

To identify the presence of putative binding sites for transcription factors, we performed a bioinformatic analysis in the promoter region of the PTGDR gene. The analysis included a 1000-bp region just before the transcription start site. In silico analysis was carried out using the MatInspector (www.genomatix.de) and Match-BioBase programs (http:// portal.biobase-international.com/).

\section{Statistical Analysis}

All data were presented as mean (SE). Data were compared using an unpaired 1-sample $t$ test using SPSS Software (version 17.0). Data were representative of at least 3 independent experiments. A value of $P<.05$ was considered significant.

\section{Results}

\section{The A549 Cell Line Does Not Express PTGDR in Basal Conditions}

We analyzed the basal expression of the PTGDR gene in the A549 cell line and did not detect mRNA expression, We also genotyped the PTGDR promoter region of A549 human lung cells to identify genetic variants, and identified the CTTT haplotype (-613 C, -549 T, -441 T, and -197 T). In addition, we studied mRNA expression of genes that code for the retinoic nuclear receptors $\operatorname{RAR} \alpha, \operatorname{RAR} \beta, \operatorname{RAR} \gamma, \operatorname{RXR} \alpha$, and the CYP26A1 RA metabolizer enzyme. These genes were not expressed in basal conditions.

\section{Genetic Variants Regulate Promoter Activity Driven by the 5'-Flanking Region of PTGDR}

To investigate the contribution of $P T G D R$ single nucleotide polymorphisms (SNPs) to PTGDR expression in cell culture, a 700-bp fragment upstream of the transcription start site of human PTGDR was amplified and cloned in the pGL3-Basic Vector. The fragments were obtained from asthmatic patients to link the model to the physiological context. Four asthmatic patients carrying the more common haplotype variants (positions -613, -549, -441 and -197) CTCT, CCCC, CCCT or TCCT were selected. The cloned regions were confirmed by sequencing.

We found significant differences in promoter activity between the haplotype variants after transient transfection analysis of the $\mathrm{A} 549$ cell line (Figure 1A). The haplotype with the wild-type CTCT sequence (-613 C, -549 T, -441 C, and -197 T), CCCT, and TCCT showed the lowest reporter activity, while CCCC showed remarkably high activity.

Promoter activity after normalization (mean [SD]) was expressed as relative luciferase units (RLU), with a value of 1 assigned to the wild-type variant CTCT. Mean RLU values were $1.22(0.08)$ for CCCC, $0.92(0.12)$ for CCCT, and 0.97 (0.04) for TCCT $(P<.001$ for all pairwise comparisons by analysis of variance, except for CCCC vs CTCT, which was $P<.05$ ) (Figure 1A).

Interestingly, the haplotype combinations with a high level of $P T G D R$ promoter activity differed from those with the lowest reporter activity in that they carried the $\mathrm{C}$ mutant variant at the -197 promoter position, No differences were observed between nontransfected cells and cells transfected with the nonmutated CTCT combination. 
A

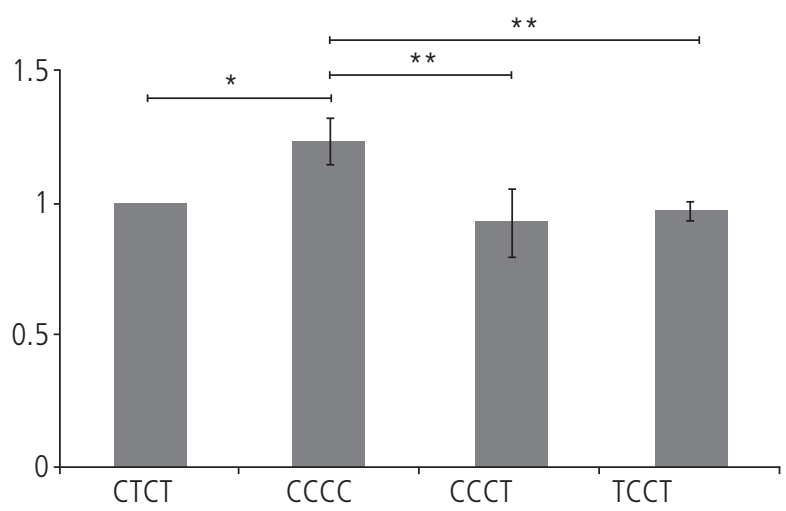

B

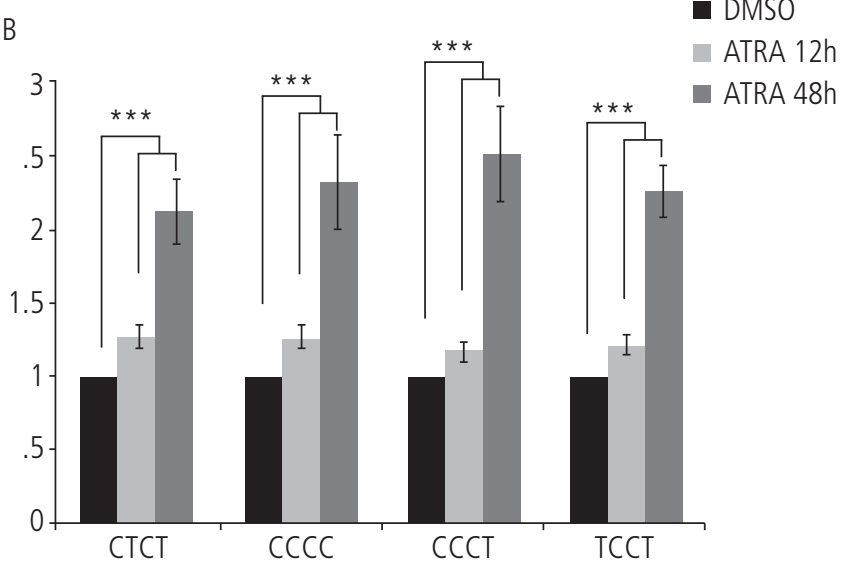

Figure 1. Transcriptional activity and ATRA modulation of the $5^{\prime}$-flanking region of PTGDR. A, A549 cells were transfected in triplicate with PTGDRluc reporter plasmid bearing the CTCT (wild-type) or CCCC, CCCT, TCCT (mutated) PTGDR promoter sequences. The graph shows the promoter activity of different haplotype variants. Each value represents the mean (SD) of light activities relative to $\mathrm{pCTCT-PTGDRluc}$ vector activity $\left({ }^{*} P<.05\right.$, $\left.{ }^{*}{ }^{*} P<.01, \mathrm{n}=3\right)$. B, A549 cells were transfected in triplicate with PTGDRluc reporter plasmid bearing the CTCT (wild-type) or CCCC, CCCT, TCCT (mutated) PTGDR promoter sequences. After transfection, cells were stimulated with 1- $\mu \mathrm{M}$ all-trans retinoic acid (ATRA) for 12 and 48 hours. Each value represent the mean (SD) of relative luciferase activity (firefly luciferase light units/Renilla luciferase light units) of ATRA relative to DMSO (value 1$)\left({ }^{* * *} P<.001, n=3\right)$.

\section{RA Selectively Stimulates Gene Expression in A549 cells}

To gain deeper insight into RA regulation mechanisms, expression of genes encoding CYP26A1 (an enzyme that regulates RA levels) and retinoic receptors $\mathrm{RAR} \alpha, \mathrm{RAR} \beta$, RAR $\gamma$ and RXR $\alpha$ was analyzed in A549 cells after stimulation with 0.01 and $1 \mu \mathrm{M}$ ATRA for 24 and 48 hours for dose response and time-course gene expression analysis (Figure 2).

Elevated levels of CYP26A1 (12-fold) and RARB (4-fold) were detected after treatment with $1 \mu \mathrm{M}$ ATRA, confirming

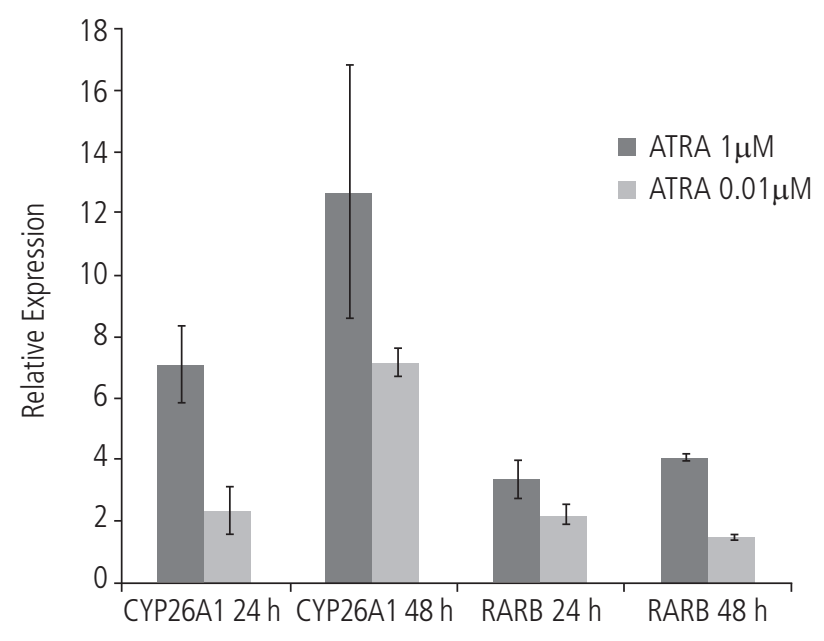

Figure 2. Quantitative real-time polymerase chain analysis (PCR) of CYP26A1 and RARB gene expression induced by all-trans retinoic acid. A549 cells were treated with 0.01 and $1 \mu \mathrm{M}$ for 24 and 48 hours followed by real-time PCR analysis of CYP26A1 and RARB mRNA. mRNA levels were normalized relative to GAPDH mRNA levels. Data are shown as fold increase relative to mRNA levels for cells treated with DSMO at the same times. activation of the RA pathway. This increase was maintained for up to 48 hours after stimulation. We did not detect expression of RARA, RARG, or RXRA in the treated A549 cell line.

$P T G D R$ mRNA was also analyzed in these cells after ATRA stimulation, but no expression was detected.

\section{RA Stimulates Promoter Activity Driven by the 5'-Flanking Region of PTGDR}

To determine whether ATRA increases PTGDR promoter activity, we examined the transcriptional activity of the 5'-flanking region of PTGDR (Figure 1B) using the dualluciferase reporter assay method normalized to cells treated with DMSO (value 1). Since the therapeutic level of ATRA in human plasma is about 1 to $2 \mu \mathrm{M}$ [17], we selected a concentration of $1 \mu \mathrm{M}$ for the luciferase experiments. When stimulated with ATRA at 12 and 48 hours, all haplotype variants exhibited higher activity $(P<.001)$. These results were confirmed in serum-free experiments to control for the possible effect of serum components.

\section{Transcription Factor Binding Site Analysis in the 5'-Flanking Region of PTGDR}

To further investigate the activation mechanism in the promoter region of $P T G D R$ we conducted different bioinformatic analyses using the MatInspector and BioBase platforms, and identified, for the first time, putative RA response element (RARE) sequences in this region on the 2 platforms. In addition, the transcription factor motifs were affected by the promoter variants. In silico studies revealed putative binding differences between wild and mutated alleles at the $-613,-549$ and -197 positions. Interestingly, these changes affected the binding affinity of the NF-AT, PAX6, EST1, PPAR, RAR, RXR, GZF1, SORY, AP-1, NBRE, ZNF652, MAZF, and SRFF transcription factors. 


\section{Discussion}

\section{The A549 Cell Line Does Not Express PTGDR in Basal Conditions}

The human PTGDR promoter region is known to exhibit genetic variability, and this is of considerable importance in asthma studies [14-16]. To test our hypothesis regarding a possible effect of RA on $P T G D R$ promoter activation, we used a cell lung model that has been applied in previous $P T G D R$ expression studies of susceptibility to asthma [14]. PTGDR expression was not detected in basal conditions, confirming the suitability of the model for analyzing the functional effects of combinations of individual PTGDR variants. Sequencing revealed that the A549 epithelial cell lung used in our experiments contained the haplotype -613 C, -549 T, $-441 \mathrm{~T}$ and $-197 \mathrm{~T}$, supporting the hypothesis that haplotype combinations carrying the T allele at position -197 negatively influence the transcriptional regulation of PTGDR [14].

\section{Genetic Variants Regulate Promoter Activity Driven by the 5'-Flanking Region of PTGDR}

The genetic variant that included the mutated $\mathrm{C}$ nucleotide at the -197 PTGDR promoter position had remarkably higher promoter activation following transient transfection in cell culture. Expression of genetic variants has been described in previous models including 3 polymorphic positions [14]. We also analyzed the -613 position, which has been linked to asthma in genetic association studies $[15,16]$.

The CTCT wild-type PTGDR haplotype (-613 C, -549T, $-441 \mathrm{C},-197 \mathrm{~T})$ has been detected more frequently in controls than in allergic individuals [18]. In our study the CCCC haplotype was significantly associated with the highest in vitro reporter activity, while the rest of haplotypes, CTCT, CCCT, and TCCT, showed significantly lower PTGDR promoter activation. The CCCC haplotype contains CCC $(-549,-441,-197)$, a combination described as a high transcriptional efficiency haplotype related to $P T G D R$ expression and previously associated with predisposition to asthma [14]. Although other SNPs or combinations may be responsible for variations in $P T G D R$ expression, according to our results the haplotype combination exerted a greater effect than individual positions.

\section{RA Selectively Stimulates Gene Expression in A549 Cells}

We investigated the expression of both RXR and RAR receptors in nontransfected A549 cells and after ATRA stimulation, and interestingly detected a selective increase in retinoid receptor expression after ATRA treatment. RA regulates inflammation, cell proliferation and differentiation, tissue development and maintenance, and immune homeostasis, modulating target gene transcription $[7,10,19,20]$. Its activity is mediated by RXR and RAR receptors. RAR isotypes differ in their $\mathrm{NH}_{2}$-terminal domain as a result of alternative promoter usage and splicing. It has been suggested that interaction between retinoids and some of their receptors overexpressed by the bronchial epithelium of patients with severe asthma may contribute to abnormal repair and airway remodeling [21]. In our study only $R A R B$ expression was detected. $R A R B$ expression has been reported to be largely dependent on RA itself and, therefore, may play a prominent role in the regulation of immune responses [22]. In addition, we detected elevated levels of the CYP26A1 gene. CYP26A1 monooxygenase inactivates ATRA through 4-hydroxylase activity. Moreover, CYP26A1 is inducible by ATRA through RARE elements in the CYP26A1 promoter region [23]. We previously reported different epigenetic patterns in $C Y P 26 A 1$ in allergic patients [24]. Both CYP26A1 and RARB have been found to be greatly inducible by ATRA in a hepatic cell model. Here we showed similar effects in an epithelial lung model.

Finally, we did not detect expression of PTGDR after ATRA treatment. We would like to highlight the fact that these cells carry the variant with the T allele at position -197 , which appears to be resistant to the effect of RA.

\section{RA Stimulates the Promoter Activity Driven by the 5'-Flanking Region of PTGDR}

We have described for the first time that RA stimulates promoter activity driven by the 5'-flanking region of PTGDR. Retinoids bind to specific RAREs in the promoter regions of target genes and function as inducible ligands by transcription factors [8]. RA has previously been associated with the prostaglandin pathway. $\mathrm{PGD}_{2}$ is the most abundantly produced COX metabolite of arachidonic acid in response to allergens and a mast cell activation marker in asthma [25]. It is synthesized by COX-1, COX-2, HPGDS, and LPGDS, and increased COX-2 expression has been found in association with ATRA [26].

The LPGDS is a binding ATRA transporter [12] and its overexpression increased the concentration of $\mathrm{T}_{\mathrm{H}} 2$ cytokines [27]. In addition, Su et al [28] showed that RA modulates cell proliferation in ovarian cancer cells through LPGDS [28]. We not only detected activation of the promoter region of PTGDR after ATRA stimulation, but also found that this activation depends on the presence of promoter combinations, although the differences did not reach statistical significance. Activation of PTGDR by RA could have important implications in immune modulation and open new insights into the field. In addition, the selective effect could explain certain discrepancies related to RA effects in allergic patients.

\section{Transcription Factor Binding Site Analysis in the 5'-Flanking Region of PTGDR}

To investigate the probable mechanisms underlying this selective promoter activation we performed an in silico analysis and found potential RARE sequences in the PTGDR promoter region. In addition, this analysis of putative binding sites showed that differential allelic occupancy at positions -613 , -549 , and -197 determines modifications in transcription factor binding that could mediate differential promoter activation, In this study only the mutated variants that bind PAX6 and ETS-1 and ZFN652 at position -549 and that bind MYC and SRF at position -197 seemed to activate the PTGDR promoter. We could therefore infer that these or other as yet unidentified transcription factors might be necessary to activate PTGDR expression. ETS-1 is involved in allergen-challenged CD4 ${ }^{+}$ cells and siRNA-mediated knockdown of ETS-1 was found to modify $\mathrm{T}_{\mathrm{H}} 2$ cytokine levels [29]. NF-AT has a key role in the 
transcription of cytokine and other genes during the immune response. It binds to the promoter of IL2, IL4, IL5, IL13, $G M-C S F$, and TNFA [30,31]. In addition, ZNF652 encodes a transcription factor that has been identified in a genome-wide association study (GWAS) of atopic dermatitis in European and Asian populations [32]. MYC, a transcription factor involved in multiple cellular processes, was also identified in the first large-scale GWAS of allergic sensitization [33]. Meanwhile, $\mathrm{SRF}$ is involved in airway remodeling in asthma, where it acts as a cofactor in association with SMAD to activate the TGF- $\beta$ signaling pathway [34].

The role of RA in allergy is not fully understood. It supports the differentiation and functional maturation of innate immune cells but how it contributes to T-cell activation is still unclear [7]. RA regulates the $\mathrm{T}_{\mathrm{H}} 1 / \mathrm{T}_{\mathrm{H}} 2$ balance [2] and in addition, the RA-dependent pathway is very important for regulating NFAT1 expression and maintaining the natural memory B cell compartment [35]. Electrophoretic mobility shift assay and chromatin immunoprecipitation assay experiments should be conducted to confirm these interesting results.

Epidemiological studies have reported both a direct and inverse association between asthma and vitamin A intake [2-4,6]. Potential benefits of therapeutic effects of ATRA or vitamin A in controlling airway inflammation in asthma may provide the basis for further investigation.

The majority of susceptibility studies are based only on descriptive analyses, not on functional analysis, which constitutes an important limitation for elucidating the mechanism by which the variants lead to asthma [14]. Our results indicate a selective response of epithelial lung cells to RA treatment, highlighting the role of the RAR $\beta$ isoform. In addition, we have described for the first time an effect of RA on the activation of the promoter region of PTGDR. We have also shown a selective response according to genetic variants, although statistical significance was not reached. Moreover, we identified RARE elements in this promoter region, and found that differential allelic occupancy at different positions determines modifications in transcription factor binding that could explain differential promoter activation. All these results provide new insights into the effects of RA and treatments based on PTGDR modulators [36], although more studies are needed to assess the relevance of these results to allergic diseases.

\section{Acknowledgments}

We thank Dr San Segundo-Val and Dr Sendin-López (University Hospital of Salamanca) for reading the manuscript and for their helpful advice and Dr Odero (CIMA, University of Navarra) for donating the pGL3-Basic Vector.

\section{Funding}

This work was supported by the Instituto de Salud Carlos III (grants PI10/01706 and PI13/00564), with European Regional Development Fund (ERDF) cofunding, by the Junta de Castilla y León (grants GRS/745/A/13 and BIO/ SA67/13), by grants from Fundación Botín-Universidad de Salamanca and Sociedad Española de Alergología e Inmunología Clínica, and by a 2013 allergy research grant from Fundación Salud 2000.

\section{Conflicts of Interest}

The authors declare that they have no conflicts of interest.

\section{References}

1. Devereux G. The increase in allergic disease: environment and susceptibility, Proceedings of a symposium held at the Royal Society of Edinburgh, 4th June 2002. Clin Exp Allergy. 2003;33(3):394-406.

2. Cantorna MT, Nashold FE, Hayes CE. Vitamin A deficiency results in a priming environment conducive for Th1 cell development. Eur J Immunol. 1995;25(6):1673-79.

3. Cui D, Moldoveanu Z, Stephensen CB. High-level dietary vitamin $A$ enhances T-helper type 2 cytokine production and secretory immunoglobulin $A$ response to influenza $A$ virus infection in BALB/C mice. J Nutr. 2000;130(5):1132-9.

4. Schuster GU, Kenyon NJ, Stephensen CB., Vitamin A deficiency decreases and high dietary vitamin $A$ increases disease severity in the mouse model of asthma. J Immunol. 2008;180(3):1834-42.

5. Kim BS, Kim IK, Park YJ, Kim YS, Kim YJ, Chang WS, Lee YS, Kweon MN, Chung Y, Kang CY. Conversion of Th2 memory cells into Foxp3+ regulatory T cells suppressing Th2-mediated allergic asthma. Proc Natl Acad Sci U S A. 2010;107(19):8742-7.

6. Nurmatov U, Devereux G, Sheikh A. Nutrients and foods for the primary prevention of asthma and allergy: systematic review and meta-analysis. J Allergy Clin Immunol. 2011;127(3):724-33.

7. Hall JA, Grainger JR, Spencer SP, Belkaid Y. The role of retinoic acid in tolerance and immunity. Immunity. 2011;35(1):13-22.

8. Chambon P. A decade of molecular biology of retinoic acid receptors. FASEB J. 1996;10(9):940-54.

9. Schug TT, Berry DC, Shaw NS, Travis SN, Noy N. Opposing effects of retinoic acid on cell growth result from alternate activation of two different nuclear receptors. Cell. 2007;129(4):723-33.

10. Alique $M$, Herrero JF, Lucio-Cazana FJ. All-trans retinoic acid induces COX-2 and prostaglandin E2 synthesis in $\mathrm{SH}$ SY5Y human neuroblastoma cells: involvement of retinoic acid receptors and extracellular-regulated kinase 1/2. J Neuroinflammation. 2007;4:1.

11. García-Solaesa V, Sanz-Lozano C, Padrón-Morales J, Hernández-Hernández L, García-Sánchez A, Rivera-Reigada ML, Dávila-González I, Lorente-Toledano F, Isidoro-García M. The prostaglandin D2 receptor (PTGDR) gene in asthma and allergic diseases. Allergol Immunopathol. 2014;42(1):64-8.

12. Tanaka T, Urade Y, Kimura H, Eguchi N, Nishikawa A, Hayaishi O. Lipocalin-type prostaglandin D synthase (beta-trace) is a newly recognized type of retinoid transporter. J Biol Chem. 1997;272(25):15789-95.

13. Murray JJ, Tonnel AB, Brash AR, Roberts LJ, 2nd, Gosset P, Workman R, Capron A, Oates JA, Release of prostaglandin D2 into human airways during acute antigen challenge. N Engl J Med. 1986:315(13):800-4.

14. Oguma T, Palmer LJ, Birben E, Sonna LA, Asano K, Lilly CM. Role of prostanoid DP receptor variants in susceptibility to asthma. N Engl J Med. 2004;351(17):1752-63.

15. Sanz C, Isidoro-Garcia M, Davila I, de Pedro MP, Mendez S de A, Padron J, Ruiz-San Francisco A, Lorente F. A new PTGDR promoter polymorphism in a population of children with asthma. Pediatr Allergy Immunol. 2009;20(2):151-6. 
16. Sanz C, Isidoro-Garcia M, Davila I, Moreno E, Laffond E, Avila C, Lorente F. Promoter genetic variants of prostanoid DP receptor (PTGDR) gene in patients with asthma. Allergy. 2006;61(5):543-8.

17. Day RM, Lee YH, Park AM, Suzuki YJ. Retinoic acid inhibits airway smooth muscle cell migration. Am J Respir Cell Mol Biol. 2006;34:695-703.

18. Isidoro-Garcia M, Sanz C, Garcia-Solaesa V, Pascual M, Pescador DB, Lorente F, Dávila I, PTGDR gene in asthma: a functional, genetic, and epigenetic study. Allergy. 2011;66(12):1553-62.

19. Wu J, Zhang Y, Liu Q, Zhong W, Xia Z. All-trans retinoic acid attenuates airway inflammation by inhibiting Th2 and Th17 response in experimental allergic asthma. BMC Immunol. 2013;14:28.

20. Druihle A, Zahm JM, Benayoun L, El Mehdi D, Grandsaigne M, Dombret MC, Mosnier I, Feger B, Depondt J, Aubier M, Pretolani $M$. Epithelium expression and function of retinoid receptors in asthma. Am J Respir Cell Mol Biol. 2008;38(3):276-82.

21. Molenaar R, Knippenberg M, Goverse G, Olivier BJ, de Vos AF, O'Toole T, Mebius RE. Expression of retinaldehyde dehydrogenase enzymes in mucosal dendritic cells and gutdraining lymph node stromal cells is controlled by dietary vitamin A. J Immunol. 2011;186(4):1934-42.

22. Tay S, Dickmann L, Dixit V, Isoherranen N. A comparison of the roles of peroxisome proliferator-activated receptor and retinoic acid receptor on CYP26 regulation. Mol Pharmacol. 2010;77(2):218-27

23. Pascual M, Suzuki M, Isidoro-García M, Padrón J, Turner T, Lorente F, Dávila I, Greally JM. Epigenetic changes in B lymphocytes associated with house dust mite allergic asthma Epigenetics. 2011;6(9):1131-7.

24. Mangelsdorf DJ. Vitamin A receptors. Nutr Rev. 1994; 52 (2 Pt 2):S32-44.

25. O'Sullivan S. On the role of PGD2 metabolites as markers of mast cell activation in asthma. Acta Physiol Scand. Suppl 1999;644:1-74.

26. Alique M, Lucio FJ, Herrero JF. Vitamin A active metabolite, all-trans retinoic acid, induces spinal cord sensitization II. Effects after intrathecal administration. $\mathrm{Br} J$ Pharmacol. 2006;149(1):65-72.

27. Fujitani Y, Kanaoka Y, Aritake K, Uodome N, Okazaki-Hatake $K$, Urade Y. Pronounced eosinophilic lung inflammation and Th2 cytokine release in human lipocalin-type prostaglandin D synthase transgenic mice. J Immunol. 2002;168(1):443-9.

28. Su B, Guan M, Xia J, Lu Y. Stimulation of lipocalin-type prostaglandin $D$ synthase by retinoic acid coincides with inhibition of cell proliferation in human $3 \mathrm{AO}$ ovarian cancer cells. Cell Biol Int. 2003;27(7):587-92.

29. Bruhn S, Barrenas F, Mobini R, Andersson BA, Chavali S, Egan BS, Hovig E, Sandve GK, Langston MA, Rogers G, Wang $H$, Benson M. Increased expression of IRF4 and ETS1 in CD4+ cells from patients with intermittent allergic rhinitis. Allergy. 2012;67(1):33-40.

30. Lavender $P$, Cousins $D$, Lee T. Regulation of Th2 cytokine gene transcription. Chem Immunol. 2000;78:16-29.

31. Hermann-Kleiter N, Baier G. NFAT pulls the strings during CD4+ T helper cell effector functions. Blood. 2010;115(15): 2989-97.
32. Ellinghaus $D$, Baurecht $H$, Esparza-Gordillo J, Rodríguez $E$, Matanovic A, Marenholz I, Hübner N, Schaarschmidt H, Novak $N$, Michel S, Maintz L, Werfel T, Meyer-Hoffert U, Hotze M, Prokisch H, Heim K, Herder C, Hirota T, Tamari M, Kubo M, Takahashi A, Nakamura Y, Tsoi LC, Stuart P, Elder JT, Sun L, Zuo X, Yang S, Zhang X, Hoffmann P, Nöthen MM, Fölster-Holst R, Winkelmann J, Illig T, Boehm BO, Duerr RH, Büning C, Brand S, Glas J, McAleer MA, Fahy CM, Kabesch M, Brown S, McLean WH, Irvine AD, Schreiber S, Lee YA, Franke A, Weidinger S. Highdensity genotyping study identifies four new susceptibility loci for atopic dermatitis. Nat Genet. 2013;45(7):808-12.

33. Bønnelykke K, Matheson MC, Pers TH, Granell R, Strachan DP, Alves AC, Linneberg A, Curtin JA, Warrington NM, Standl M, Kerkhof M, Jonsdottir I, Bukvic BK, Kaakinen M, Sleimann P, Thorleifsson G, Thorsteinsdottir U, Schramm K, Baltic S, KreinerMøller E, Simpson A, St Pourcain B, Coin L, Hui J, Walters EH, Tiesler CM, Duffy DL, Jones G, Ring SM, McArdle WL, Price L, Robertson CF, Pekkanen J, Tang CS, Thiering E, Montgomery GW, Hartikainen AL, Dharmage SC, Husemoen LL, Herder C, Kemp JP, Elliot $P$, James A, Waldenberger $M$, Abramson MJ, Fairfax BP, Knight JC, Gupta R, Thompson PJ, Holt P, Sly $P$, Hirschhorn JN, Blekic $M$, Weidinger $S$, Hakonarsson $H$, Stefansson K, Heinrich J, Postma DS, Custovic A, Pennell CE, Jarvelin MR, Koppelman GH, Timpson N, Ferreira MA, Bisgaard $\mathrm{H}$, Henderson AJ; Australian Asthma Genetics Consortium (AAGC); EArly Genetics and Lifecourse Epidemiology (EAGLE) Consortium. Meta-analysis of genome-wide association studies identifies ten loci influencing allergic sensitization. Nat Genet. 2013;45(8):902-6.

34. Schuliga $M$, Javeed $A$, Harris $T$, Xia $Y$, Qin C, Wang Z, Zhang $X$, Lee PV, Camoretti-Mercado B, Stewart AG. Transforming growth factor- $\beta$-induced differentiation of airway smooth muscle cells is inhibited by fibroblast growth factor-2. Am J Respir Cell Mol Biol. 2013;48(3):346-53.

35. Maruya M, Suzuki K, Fujimoto $H$, Miyajima M, Kanagawa $O$, Wakayama T, Fagarasan S. Vitamin A-dependent transcriptional activation of the nuclear factor of activated T cells c1 (NFATc1) is critical for the development and survival of B1 cells. Proc Natl Acad Sci U S A. 2011. Jan 11;108(2):722-7.

36. Bain $G$, King $C D$, Brittain J, Hartung JP, Dearmond I, Stearns B, Truong YP, Hutchinson JH, Evans JF, Holme K. Pharmacodynamics, pharmacokinetics, and safety of AM211: a novel and potent antagonist of the prostaglandin D2 receptor type 2. J Clin Pharmacol. 2012 Oct;52(10):1482-93.

- Manuscript received April 13, 2015; accepted for publication, December 15, 2015.

\section{- María Isidoro}

Departamento de Bioquímica Clínica Complejo Hospitalario de Salamanca Paseo de San Vicente 58 37007, Salamanca, Spain E-mail: misidoro@usal.es 